\title{
Victims as Stakeholders: Insights from the Intersection of Psychosocial, Ethical, and Crisis Communication Paths
}

\author{
Wouter Jong ${ }^{1} \oplus$ and Kjell Brataas ${ }^{2}$ () \\ 1. Faculty of Governance and Global Affairs, Leiden University, The Hague, \\ The Netherlands \\ 2. Ministry of Transport, Oslo, Norway
}

\section{ABSTRACT}

This article examines the position of victims and those affected within communication theory. Current research has broadly been skewed toward reputation management and protecting brand value as primary goals of crisis communication efforts. As crises affect real people, crisis communication theory needs to be adapted to include their needs. To assure their needs are met, an integration of business ethics and psychosocial mechanisms in the field of crisis communication is proposed. This integration prevents crisis communication output from becoming an additional source of stress to the affected in the aftermath of crises. We offer recommendations for crisis communication scholarship to be inclusive and beneficial to victims and the affected in the aftermath of crises.

KEYWORDS: victims, psychosocial, aftermath, remembrances, ethics of care

Crises and disasters such as terrorist attacks, earthquakes, airplane crashes, and hurricanes cause serious psychosocial harm to exposed individuals and put families, neighborhoods, and communities at risk (Bonanno et al., 2010). Typical effects include stress, fear, uncertainty, physical symptoms, and trauma-related mental health problems (Dückers et al., 2017). Even though the first priority in crisis management and crisis communication

CONTACT Wouter Jong (D) - E-mail: w.jong@fgga.leidenuniv.nl • Leiden University, Wijnhaven, Turfmarkt 99, 2511 DP The Hague • The Netherlands 
should be to help victims and protect potential victims from harm (Coombs, 2007; Coombs \& Holladay, 2007; Sturges, 1994), this dimension of crisis communication has received little attention in the crisis communication literature. The field turns out to have a "managerial bias" (Waymer \& Heath, 2007), with a focus on reputation and American corporate case studies (Arendt et al., 2017). On a day-to-day business, restoring the reputation of the organization and the trust of customers or other stakeholders is considered as the "foremost goal of crisis communication" (Utz et al., 2013). Over the years, protecting brand reputation and brand value became the focal point of crisis response strategies, while the role of affected victims seems to be diminished. The needs of victims in crisis communication scholarship is often minimized to apologies (Coombs \& Laufer, 2018) and expressions of sympathy.

However, from psychosocial literature, we know that victims look for acknowledgment of the difficult situation they find themselves in (Maercker \& Müller, 2004). Providing meaning to something can have a positive effect on people's resilience and recovery from stressful events as well (Park, 2016). Providing meaning to a horrible situation in a broader context is usually considered as one of the public leadership tasks, in which the broader impacts of a crisis are communicated to citizens, the media, and other stakeholders (Boin et al., 2005; Jong, 2017). As such, providing meaning can be regarded as another form of expressing sympathy to victims and the affected. Well-known examples are the performances of public leaders like Mayor Giuliani after 9/11 or Prime Minister Ardern of New Zealand in the aftermath of the Christchurch mosque shooting. Finding words on behalf of the government is not solely driven by reputations or the perspective of future elections, but has a more public-oriented goal, which is to strengthen society, provide hope (Noordegraaf \& Newman, 2011; Pennebaker \& Lay, 2002), and call upon resilience and pride (De Bussy \& Paterson, 2012). As part of his situational crisis communication theory (SCCT), Coombs (2010) states that victims not only should be provided with an expression of sympathy, but also with information about corrective actions, and trauma counseling when needed. Although it is hard to define corrective action and trauma counseling as part of the realm of crisis communication 
per se, the way in which crisis communication should live up to the expectations of victims beyond the expressions of sympathy remains unclear.

This is important, as case studies show that victims sometimes expect more than sympathy, corrective action, or trauma counseling. Recently, Boeing had a hard time in 2018 and 2019, as their brand-new Boeing 737 Max plane experienced fatal crashes on two occasions. After the second crash in Ethiopia, the Boeing company expressed its deepest sympathies to the families and loved ones of those who lost their lives in the accident (Boeing, 2019). The wording was similar to its statement after the first crash in Indonesia. In a New York Times article (New York Times, 2019), relatives expressed their disappointment in the company, as Boeing did not learn from the first incident. According to them, it was "absolutely inexcusable that it takes another crash for people to kick this investigation and improvements into high gear." The example shows that victims can be influential stakeholders who sometimes voice their specific needs. On this occasion, they needed more than just condolences. They wanted Boeing to show that it learned from the accident.

It is a challenge for crisis communication scholarship to align victim-oriented communication with reputation-driven communication, as both ask for rather different requirements in communication. Crisis communication that is beneficial for the restoration of a corporate reputation has different goals than the sole wellbeing of victims. Heath (2010) explains why victims might judge a situation differently compared to an organization, when faced with a crisis. He gives the example of victims (individual and community) of a deadly mining operation, to whom it may be more of a crisis than it is for the owners and managers of the company. As long as crisis communication research tends to focus on the reputation of the mining company, the well-being of victims and their next of kin might be overshadowed. Alternatively, the needs of victims cannot be regarded as more important than reputation.

We argue that crisis communication has an ethical duty to support victims who cope with the consequences of a crisis and find ways in which it fits within the broader attempt to restore reputations. This implies that communicative awareness is warranted 
to better understand the needs of victims and how crisis communication as a practice can contribute to fulfilling those needs. Otherwise, without such awareness, the output of crisis communication might become an additional source of stress and trigger negative consequences to people who are faced with a crisis or disaster. As in Heath's (2010) example, the focus on the reputation of the mining company overshadows the needs of the coworkers from the mining company. Such sources of stress go beyond short-term conflicting or unclear messages from authorities and experts, which are considered to enhance temporary uncertainty and worry among the public (Gouweloos et al., 2014). Our goal is to take it one step further and assess the potential contribution of crisis communication to prevent long-lasting, individual, and psychosocial problems in the aftermath of tragic events.

This article aims to integrate psychosocial principles into crisis communication theory, which enables practitioners to lower experienced stress among victims. Additionally, we aim to generate more depth to the "expression of sympathy" and develop a set of communicative interventions that support victims in times of crisis. In short, the goals are as follows: (1) to define and extend our understanding of the interests of those directly affected in times of crisis and (2) to make communicative recommendations for when an organization, either public or private, is faced with people who suffer from an incident or crisis. First, an overview is given of the current literature on the overlap between business ethics, psychosocial, and crisis communication literature. Then, an outline is given for a series of building blocks to apply psychosocial principles to crisis communication. These building blocks support communication practitioners who might otherwise underestimate the needs of individual victims. Finally, directions for further research are described.

\section{Ethics of Care Perspective}

In order to intertwine reputation-driven communication with victim-oriented communication, there is a need for a stakeholder approach that balances economic, financial, and reputational consequences with the interests of the directly affected. An ethic of 
care approach, as initially outlined by Gillian (1982), emphasizes how one's actions may impact the feelings of others (Bauman, 2011). As such, it scans the environment on the impact of a crisis among stakeholders and provides a caring response which ultimately strengthens the relationship between the corporation and its customers. This is similar to Marynissen and Lauder's (2020) argument that the communication strategy has to prioritize the concerns raised by those involved in the crisis. In their case study on the Brussels terror attacks in March 2016, they describe how the federal crisis center addressed these concerns in their communication approach (Marynissen \& Lauder, 2020).

From this perspective, the organization under crisis takes care of its responsibilities to others, not because it is legally obliged to do so, but because they voluntarily want to act (Simola, 2003). In the ethics of care approach, the organization acknowledges the harm, apologizes, and acts to resolve the problem (Bauman, 2011; Diers-Lawson \& Pang, 2016). As Bauman notes, the level of care required to effectively manage a crisis remains an open question. It is not likely that there is a "one size fits all" approach, as everyone experiences a crisis situation differently. The particular setting of private, personal, and public life influences the way in which people experience the impact of a crisis and the meaning they assign to an event (Jong \& Dückers, 2019). These perceptions might change over time (Dyb et al., 2014; Perry and Lindell, 2003).

Even though the concerns and expectations might differ from one victim to another, the type of concerns can be generalized. To get an impression of the needs of those who became a victim of a crisis, we turn to Hobfoll et al. (2007) who developed a psychosocial model for supporting those who have experienced traumatic events. Their model is widely used within the psychosocial domain and includes the recommended prevention approach in the immediate aftermath of events, before clinically significant psychiatric symptoms emerge (Neria \& Shultz, 2012). According to Hobfoll et al. (2007, p. 285), there are five so-called "essential elements" that are beneficial for the well-being of the affected. These "essential elements" are widely referred to as elements that support victims to recover from stressful events. These are the promotion of a sense of safety, calmness, self- and community 
efficacy, connectedness to others, and hope. Further minimization of sources of stress to victims implies that crisis communication should incorporate these essential, psychosocial elements in its approach. Translating these essential elements to the domain of crisis communication enables us to contribute to a caring response and to fulfill the needs of the affected.

\section{Hobfoll et al.'s Principles as Building Blocks for Crisis Communication}

Our objective is to enable crisis communication practitioners to work along the lines of these psychosocial principles through the lens of an ethics of care perspective. For this reason, we translate Hobfoll et al.s (2007, p. 285) "essential elements" to a crisis communication setting in more detail and illustrate them with examples. In doing so, one has to realize that crisis communication can contain more than one element at once. By incorporating the elements in this approach, they can work as building blocks for coherent and consistent crisis communication which incorporates the ethics of care perspective.

\section{Promote a Sense of Safety}

According to Hobfoll et al. (2007), statements made can support a sense of safety. Transferred to communication practice, communication about the lessons learned from a crisis can support victims to cope with the situation. Is the organization open to communication with the affected? Do the affected feel supported by the organization and others, or do they feel left alone in their own sorrow? Only direct contact with victims or their representative groups enables organizations to prevent tensions from arising in the aftermath of the event, rooted in differences of expectations. Support in media management after crises is another field where organizations can contribute to lower distress among the affected. Restraint in media coverage might help them to limit unwanted exposure for those who are hesitant to share their personal grief in the public arena. Kwesell and Jung (2019) conclude, based on an analysis of the aftermath of the Fukushima nuclear (2011) disaster, that crisis communication experts should put immediate 
focus on local media and encourage them to take on active roles to overcome negative effects by the mainstream media's framed stories. In other cases, one might think of supporting victims in media management. This support includes advising victims who consider giving media interviews and pointing out the long-lasting effects of venting frustration on social media. Not necessarily in the interest or in cooperation with all victims, several disasters have been made into feature-length movies. Discussing pros and cons of such movies with the directly affected seems key, as it often stirs controversy and debate, and scholars, victims, and the public disagree amongst themselves about when (if ever) is a good time for such a movie to be released. In 2018, several movies and a TV series depicted the terror in Norway. Utøya 22 July by Erik Poppe was first shown to members of a support group so that they could see it-and advise others-before its main release. Promoting safety implies communicating with all parties involved and support them in anticipating on developments in the aftermath (e.g., court cases, investigation reports). Be aware of the impact of commemorations and remembrances, anticipate "anniversaries," and show that the organization cares about all different opinions on the road ahead.

\section{Promote Calming}

Regarding the promotion of calming, effective messages include: "You are neither sick nor crazy; You are going through a crisis; You are reacting in a normal way to an abnormal situation" (Hobfoll et al., 2007, p. 291; see also Solomon, 2003). The New Zealand government set up a national response and recovery plan after the Christchurch Mosque shooting, where communication efforts were made to promote population level well-being and offer access to support for survivors and their families (New Zealand Ministry of Health, 2019).

There is a need for guidance regarding what will happen next. Most victims are in a completely new situation and often have many concrete questions about the next steps, including when they will be informed about the status of their loved ones, what will happen to personal possessions, and how the process of 
identifying remains works. Part of this process includes acknowledging uncertainty, as Prime Minister Rutte from The Netherlands did during the COVID-19 crisis. In one of his press statements, he stressed that the government had to make $100 \%$ of the decisions with $50 \%$ of the knowledge.

Calming can be promoted by means of a physical family assistance center, as it can function as a "one-stop-shop" providing vital information for victims of the disaster (Brataas, 2018, p. 140). This applies not only to the public sector, but to the commercial sector as well. A best practice to consider is the action of the Norwegian oil company Equinor, which experienced a major crisis in 2013 when many of its employees in In Aménas, Algeria, were taken hostage. Equinor set up a family assistance center at a local hotel in Norway and invited family members of those missing to come and stay for as long as needed. After a short while, Equinor took over the whole hotel, and senior staff from Equinor-occasionally including the CEO-gave hourly briefings about the situation. This action was later praised by officials and families and proved that crisis communication, crisis leadership, and psychosocial support need to interact for optimum effectiveness (Brataas, 2018).

Calmness also includes organizations sticking to the promises they made, as victims want to know what they can expect in the near future. As a crisis winds down, it can be important to acknowledge victims in their wish to understand why a crisis occurred (Jong, 2019) and to inform them personally as soon as a final investigation on the cause of a crisis is made public. Such a report will possibly function as closure to the public, which asks for a well communicated process to help alleviate continuing anxiety and encourage the return to a state of normality (Baubion, 2013).

\section{Promote a Sense of Self- and Collective Efficacy}

Activities set up by communities may contribute to a sense of collective efficacy. Communities and colleagues play a role by helping victims to self-organize, collectively make sense of a crisis, and reproduce community experiences $(\mathrm{Xu}, 2018)$. Resources are needed to encourage empowerment; otherwise initiatives can be counterproductive and demoralizing. Support groups can act as 
venues for peer support and collectively gathering information and deciding on a collective way forward for those affected. One topic of discussion might be a monument to memorialize the tragedy. The process of deciding on whether to establish a permanent memorial and subsequently on its design often leads to political and sensitive discussions (de Roy van Zuijdewijn, 2019), which can be a long-lasting and sometimes frustrating task to agree on. It fits with a call by Austin et al. (2014), who emphasize the need for repairing symbolic and physical damage and bringing forth victims' voices in the aftermath.

Efficacy might be stimulated through charities as well. Charities in the wake of a tragedy are probably more common in the U.S. than elsewhere in the world. They can mean a new beginning for victims and, if handled correctly, a charity can become a symbol for a city united and people willing to help each other. One of the best examples is the One Fund Boston, which was initiated less than 24 hours after the terror attack on the Boston Marathon. It received more than USD 80 million from 200,000 individuals, groups, and businesses.

In their analysis of the Fukushima nuclear disaster (2011), Kwesell and Jung (2019) propose that disaster response and communication strategies should include ways for residents to talk openly about their difficulties, uncertainties, and frustrations. This would allow victims to share information in a safe space, voice anxieties and concerns, and come to some agreement on strategies moving forward.

\section{Promote Connectedness}

Promoting connectedness involves more than online forums where the affected can meet. In their study, Procopio and Procopio (2007) specifically stressed the importance of offline communication, which seems more efficient in building and strengthening the weak ties in each community or a social business-oriented network among colleagues. It includes facilitating and attending memorials and remembrances, which enable those affected to meet each other. The National September 11 Memorial \& Museum in New York is perhaps the largest and most well-known example, 
but other recent monuments include the Atocha station memorial in Madrid and the 7 July Memorial in Hyde Park in London (de Roy van Zuijdewijn, 2019). Remembrances are held throughout the world regularly as well. As an example, Spain's King Felipe has led a ceremony in Madrid to honor the almost 30,000 people who have died from the COVID-19 pandemic in the country, while German Chancellor Angela Merkel attended a ceremony 1 year after the Berlin terrorist attack. The intensity of such gatherings varies. Some officials attend local remembrances year after year, such as the Mayor of London and the head of the Metropolitan police who lay wreaths at a memorial to the 7 July attacks in Hyde Park, London, while others only attend specific anniversary years.

Apart from remembrances, there are many other examples of this theory in practice, such as a variety of support groups that formed after disasters with the fundamental purpose to make changes and to ensure that a similar tragedy will not happen again. Sometimes their actions are so forceful that laws change-as was the case in the U.S. in the 1990 s when support groups after airline accidents led to The Aviation Disaster Family Assistance Act of 1996 and the Foreign Air Carrier Family Support Act of 1997.

\section{Promote Hope}

The concept of "hope" fits within the recent discourse of renewal research. This theory states that circumstances can ask for a prospective outlook that emphasizes positive change during the post-crisis period (Wombacher et al., 2018). The post-crisis discourse of renewal is characterized by four dominant features: prospective focus, the opportunities inherent in the crisis, provisional rather than strategic responses, and ethical communication grounded in core values (Seeger \& Ulmer, 2002; Seeger et al., 2005; Ulmer \& Sellnow, 2002). The ethical communication agenda of the discourse of renewal is value-driven and refers to acting in a manner consistent with general social values before, during, and after the crisis (Ulmer et al., 2007).

Hope can be provided on both a community and an individual level. Aforementioned De Bussy and Paterson (2012) assessed the communicative styles of public leaders after floods in Queensland, Australia. During the floods, Queensland Premier Anna Bligh 
provided hope to her citizens. In her statements she stressed that it does not matter where people live, whether it is in the capital city or the tiniest country towns, every single person affected by this event is going to be looked after and "won't be forgotten." While this example refers to providing hope to a community under stress, crisis managers can also offer hope on a more individual level. When an organization shows that it has truly learned from a crisis, this helps the affected in the sense that it did not happen "for nothing."

\section{Implications for Practice}

As a first step, we combined the needs of victims, expressed in psychosocial principles of the five so-called "essential elements" (Hobfoll et al., 2007) with crisis communication practice. On the following page, Table 1 summarizes the recommendations for aligning the elements and crisis communication. The lessons are clustered according to the five principles in order to guide practitioners to fulfill a communicative role in the provision of psychosocial support.

Taking care of the needs of victims is, of course, beneficial to them. To decide the level of care that is needed, organizations should reach out and discuss expectancies with individual victims and those affected. Such a conversation activates a range of relevant stakeholders with divergent voices, where the organization needs to ensure that the voice of none of these stakeholders is inhibited (Simola, 2003). The approach does not necessarily conflict with communication goals based on reputation management and can be beneficial to the organization involved as well. Simola describes a case study on crisis management by McDonald's after a fatal shooting at the San Ysidro, California, McDonald's restaurant in 1984. The company invested in its relations with the community and took care of them in the aftermath. Again, not because it was legally obliged to do so, but because it voluntarily wanted to act. Although the expressed goal of McDonald's Corporation was not reputationally driven, the ethic of care that it demonstrated during a time of horrific pain and suffering was appreciated by the public and press (Simola, 2003). The process of listening to and acting upon the needs of victims is not an easy task and takes time. 
TABLE 1 Communicative Contributions Applied to Hobfoll et al.'s (2007) Essential Elements

\begin{tabular}{|c|c|}
\hline Category & $\begin{array}{l}\text { Recommendations for Crisis Communication } \\
\text { Practitioners }\end{array}$ \\
\hline Sense of safety & $\begin{array}{l}\text { - Share what the organization learned from the tragedy } \\
\text { - Restraint in media coverage or support the affected in } \\
\text { media management } \\
\text { - Prevent or limit unwanted exposure (such as movies } \\
\text { and TV series) } \\
\text { - Keep direct contact with victims or their representa- } \\
\text { tives throughout the aftermath } \\
\text { - Coordinate commemorations and remembrances } \\
\text { - Show that the organization cares about all different } \\
\text { opinions among victim groups }\end{array}$ \\
\hline Calmness & $\begin{array}{l}\text { - Support mental health messages } \\
\text { - Stick to promises made } \\
\text { - Address concerns } \\
\text { - Guide them and tell them what will be the next steps } \\
\text { in the process } \\
\text { - Provide vital information in an easily accessible manner }\end{array}$ \\
\hline $\begin{array}{l}\text { Self- and } \\
\text { community } \\
\text { efficacy }\end{array}$ & $\begin{array}{l}\text { - Stimulate self-organizing communities or colleagues } \\
\text { with empowering communication } \\
\text { - Consider support for a monument to memorialize the } \\
\text { tragedy to bring forth victims' voices } \\
\text { - Consider support in fundraising to mark a new } \\
\text { beginning in the aftermath }\end{array}$ \\
\hline $\begin{array}{l}\text { Connectedness } \\
\text { to others }\end{array}$ & $\begin{array}{l}\text { Provide meaning and describe the shared feelings } \\
\text { among victims and the affected } \\
\text { - Enable victims to share their thoughts in a safe } \\
\text { environment (Kwesell \& Jung, 2019) } \\
\text { - Discuss communicative needs in terms of } \\
\text { connectedness, both online and offline } \\
\text { - Facilitate attending memorials and remembrances }\end{array}$ \\
\hline Hope & $\begin{array}{l}\text { - Communicate a prospective outlook to emphasize } \\
\text { positive change when suited (see discourse of renewal, } \\
\text { e.g., Seeger \& Ulmer, 2002) } \\
\text { - Be consistent in communicating values before, during, } \\
\text { and after the crisis } \\
\text { - Show that the organization learned from the crisis and } \\
\text { it did not happen "for nothing" } \\
\text { - Be transparent and accessible by just being there and } \\
\text { using well-chosen words to support victims in their } \\
\text { suffering }\end{array}$ \\
\hline
\end{tabular}


Experience from Norway shows that stakeholders sometimes need time to change their mind and align with the steps taken by others. Families who did not participate in the construction of a memorial after the Utøya shooting asked to have the names of their relatives added, shortly after the memorial site was opened (de Roy van Zuijdewijn, 2019).

\section{Future Directions}

From the point of view of the affected, image restoration and restoring the brand value of the organization under crisis is not a priority they are interested in. After having survived an airplane crash, survivors might develop a negative brand image of the airline at stake, although it is more likely that they develop a general fear of flying that is not aimed at one brand specifically. Even more importantly, apart from fear, they might suffer from stress, uncertainty, physical symptoms, and trauma-related mental health problems in the aftermath of crises.

In their commentary, Liu and Fraustino (2014, p. 546) raised the fundamental question: "What is the goal of our scholarship?" We believe that bridging the commercial and reputational interests of organizations and the more private interests of the directly affected is one such goal. We echo Hayes et al's (2017) call to come to a new paradigm, as current typologies of crisis response fail to account for organizations' moral or professional obligation to respond to support the well-being of victims. Such a new paradigm supports organizations in their efforts to integrate a more resilience-oriented type of crisis communication and support communities to survive and revive in the event of a crisis (e.g., Olsson, 2014).

A focus on brand image without taking care of the needs of victims and their families creates additional and unnecessary sources of stress to them. It is an ethical duty of our scholarship to incorporate the interests of the directly affected in crisis communication and create caring and valuable communication toward all stakeholders. While image restoration strategies might be helpful to other audiences (e.g., network partners, shareholders, customers), reputational strategies are counterproductive when targeted to victims and the affected as a specific group of stakeholders. 
The psychosocial principles, introduced by Hobfoll et al. (2007), are a guide for those organizations that want to adopt the ethics of care perspective in their communication after tragic events. Whatever direction is taken, it implies a long-lasting commitment to victims in terms of crisis communication.

Additional research should further focus on the specific psychosocial needs of the affected, the role of these needs within the broader discourse of crisis communication, and how to align them with the interests of other stakeholders of organizations under crisis.

\section{Conclusion}

Current crisis response strategies tend to focus on "image restoration" as their primary goal, where protecting the reputation and brand value seem key. Using such strategies might give practitioners the false impression that the support for victims is limited to an expression of sympathy, providing information about corrective actions, and referring to trauma counseling when needed. From an ethics of care perspective (Simola, 2003), organizations should look beyond what they are legally obliged to do. This asks for organizations to listen to victims and their next of kin, and show that they voluntarily want to act upon their needs. Such a process of listening and acting is not an easy task and takes time. But demonstrating and communicating from an ethic of care approach during times of crisis is likely to contribute to the well-being of victims and their next of kin.

When the ethics of care perspective is applied to crisis communication, it deepens our understanding of the merits of expressing sympathy. The current study claims that the crisis communication approach of expression of sympathy is multilayered and can be further detailed on the basis of five essential elements of immediate and midterm mass trauma intervention (Hobfoll et al., 2007). The communicative recommendations proposed in Table 1 can be regarded as communicative interventions to prevent or lower stress, fear, uncertainty, physical symptoms, and other traumarelated mental health problems among victims and their families. 


\section{ORCID}

Wouter Jong (i) https://orcid.org/oooo-0001-9752-4852

Kjell Brataas (ㄱ) https://orcid.org/oooo-00o2-2392-8261

\section{References}

Arendt, C., LaFleche, M., \& Limperopulos, M. A. (2017). A qualitative meta-analysis of apologia, image repair, and crisis communication: Implications for theory and practice. Public Relations Review 43(3), 517-526. https://doi.org/10.1016/j. pubrev.2017.03.005

Austin, L. L., Liu, B. F., \& Jin, Y. (2014). Examining signs of recovery: How senior crisis communicators define organizational crisis recovery. Public Relations Review, 4o(5), 844-846. https:// doi.org/10.1016/j.pubrev.2014.06.003

Baubion, C. (2013). OECD risk management: Strategic crisis management. OECD Working Papers on Public Governance, No. 23, OECD Publishing, Paris. https://doi.org/10.1787/5k41r bdilzr7-en

Bauman, D. C. (2011). Evaluating ethical approaches to crisis leadership: Insights from unintentional harm research. Journal of Business Ethics, 98, 281-295. https://doi.org/10.1007/s10551010-0549-3

Boeing. (2019, 10 March). Boeing statement on Ethiopian Airlines Flight 302. https://web.archive.org/web/20190405113 229/https://boeing.mediaroom.com/2019-04-04-BoeingStatement-On-Ethiopian-Airlines-Flight-302-InvestigationPreliminary-Report

Boin, A., 't Hart, P., Stern, E., \& Sundelius, B. (2005). The politics of crisis management: Public leadership under pressure. Cambridge University Press.

Bonanno, G. A., Brewin, C. R., Kaniasty, K., \& La Greca, A. M. (2010). Weighing the costs of disaster: Consequences, risks, and resilience in individuals, families, and communities. Psychological Science in the Public Interest, 11, 1-49. https:// doi.org/10.1177/1529100610387086

Brataas, K. (2018). Crisis communication: Case studies and lessons learned from international disasters. Taylor \& Francis. 
Coombs, W. T. (2007). Protecting organization reputations during a crisis: The development and application of situational crisis communication theory. Corporate Reputation Review, 10(3). 163-177. https://doi.org/10.1057/palgrave.crr.1550049

Coombs, W. T. (2010). Parameters for crisis communication. In W. T. Coombs and S. J. Holladay (Eds.). The Handbook of Crisis Communication (pp. 17-53). Wiley-Blackwell.

Coombs, W. T., \& Holladay, S. (2007). The negative communication dynamic: Exploring the impact of stakeholder affect on behavioral intentions. Journal of Communication Management, 11(4), 300-312. https://doi.org/10.1108/13632540710843913

Coombs, W. T., \& Laufer, D. (2018). Global crisis management: Current research and future directions. Journal of International Management, 24(3), 199-203.https://doi.org/10.1016/j.intman .2017 .12 .003

De Bussy, N. M., \& Paterson, A. (2012). Crisis leadership stylesBligh versus Gillard: A content analysis of Twitter posts on the Queensland floods. Journal of Public Affairs, 12(4), 326-332. https://doi.org/10.1002/pa.1428

de Roy van Zuijdewijn, J. (2019). Remembering terrorism: The case of Norway. ICCT Commentary. https://web .archive.org/web/20191001112303/https://icct.nl/publication/ remembering-terrorism-the-case-of-norway/

Diers-Lawson, A., \& Pang, A. (2016). Did BP atone for its transgressions? Expanding theory on 'Ethical apology' in crisis communication. Journal of Contingencies and Crisis Management, 24, 148-161. https://doi.org/10.1111/1468-5973.12110

Dückers, M. L. A., Yzermans, C. J., Jong, W., \& Boin, A. (2017). Psychosocial crisis management: The unexplored intersection of crisis leadership and psychosocial support. Risk, Hazards \& Crisis in Public Policy, 8(2), 94-112. https://doi.org/10.1002/ rhc 3.12113

Dyb, G., Jensen, T., Nygaard, E., Ekeberg, Ø., Diseths, T., WentzelLarsen, T., \& Thoresen, S. (2014). Post-traumatic stress reactions in survivors of the 2011 massacre on Utøya Island, Norway. British Journal of Psychiatry, s204(5), 361-367. https:// doi.org/10.1192/bjp.bp.113.133157 
Gillian, C. (1982). In a different voice. Harvard University Press. Gouweloos, J., Dückers, M., te Brake, H., Kleber, R., \& Drogendijk, A. (2014). Psychosocial care to affected citizens and communities in case of CBRN incidents: A systematic review. Environment International, 72, 46-65. https://doi. org/10.1016/j.envint.2014.02.009

Hayes, R. A., Waddell, J. C., \& Smudde, P. M. (2017). Our thoughts and prayers are with the victims: Explicating the public tragedy as a public relations challenge. Public Relations Inquiry, 6(3), 253-274. https://doi.org/10.1177/2046147X16682987

Heath, R. L. (2010). Introduction crisis communication: Defining the beast and de-marginalizing key publics. In W. T. Coombs and S. J.Holladay (Eds.), The Handbook of Crisis Communication (pp. 7-8). Wiley-Blackwell.

Hobfoll, S. E., Watson, P., Bell, C. C., Bryant, R. A., Brymer, M. J., Friedman, M. J., Friedman, M., Gersons, B. P. R., de Jong, J. T. V. M., Layne, C. M., Maguen, S., Nerla, Y., Norwood, A. E., Pynoos, R. S., Reissman, D., Ruzek, J. I., Shalev, A. Y., Solomon, Z., Steinberg, A. M., \& Ursano, R. J. (2007). Five essential elements of immediate and mid-term mass trauma intervention: Empirical evidence. Psychiatry, 7o(4), 283-315. https://doi. org/10.1176/foc.7.2.foc221

Jong, W. (2017). Meaning making by public leaders in times of crisis: An assessment. Public Relations Review, 43, 1025-1035. https://doi.org/10.1016/j.pubrev.2017.09.003

Jong, W. (2019). Anticipating the unknown: Crisis communication while under investigation. Public Relations Inquiry. https://doi. org/10.1177/2046147X19862343

Jong, W., \& Dückers, M. L. A. (2019). The perspective of the affected: What people confronted with disasters expect from government officials and public leaders. Risk, Hazards \& Crisis in Public Policy, 10, 14-31. https://doi.org/10.1002/rhc3.12150 Kwesell, A., \& Jung, J. Y. (2019). A multidimensional analysis of stigma: Findings from a qualitative study of Fukushima residents following Japan's 2011 nuclear disaster. Journal of International Crisis and Risk Communication Research, 2(2), 233-258. https://doi.org/10.30658/jicrcr.2.2.4 
Liu, B. F., \& Fraustino, J. D. (2014). Beyond image repair: Suggestions for crisis communication theory development. Public Relations Review, 4o(3), 543-546. https://doi. org/10.1016/j.pubrev.2014.04.004

Maercker, A., \& Müller, J. (2004). Social acknowledgment as a victim or survivor: A scale to measure a recovery factor of PTSD. Journal of Traumatic Stress, 17(4), 345-351. https://doi. org/10.1023/B:JOTS.0000038484.15488.3d

Marynissen, H., \& Lauder, M. (2020). Stakeholder-focused communication strategy during crisis: A case study based on the Brussels terror attacks. International Journal of Business Communication, 57(2), 176-193. https://doi. org/10.1177/2329488419882736

Neria, Y., \& Shultz, J. M. (2012). Mental health effects of Hurricane Sandy: Characteristics, potential aftermath, and response. JAMA,308(24),2571-2572.https://doi.org/10.1001/jama.2012. 110700

New York Times. (2019, April 2). Between two Boeing crashes, days of silence and mistrust.

New Zealand Ministry of Health. (2019). Supporting people affected by the Christchurch mosque attacks: National response and recovery plan to 15 March 2020. Ministry of Health. https://web.archive.org/web/20210113161246/ https://www.health.govt.nz/system/files/documents/pages/ supporting-people-_affected-christchurch-mosque-attacksjul19.pdf

Noordegraaf, M., \& Newman, J. (2011). Managing in disorderly times: How cities deal with disaster and restore social order, Public Management Review, 13(4), 513-538. https://doi.org/10 $.1080 / 14719037.2010 .525035$

Olsson, E. K. (2014). Crisis communication in public organisations: Dimensions of crisis communication revisited. Journal of Contingencies and Crisis Management, 22(2), 113-125. https:// doi.org/10.1111/1468-5973.12047

Park, C. L. (2016). Meaning making in the context of disasters. Journal of Clinical Psychology, 72(12), 1234-1246. https://doi. org/10.1002/jclp.22270 
Pennebaker, J. W., \& Lay, T. C. (2002). Language use and personality during crises: Analyses of Mayor Rudolph Giuliani's press conferences. Journal of Research in Personality, 36(3), 271-282. https://doi.org/10.1006/jrpe.2002.2349

Perry, R. W., \& Lindell, M. K. (2003). Understanding citizen response to disasters with implications for terrorism. Journal of Contingencies and Crisis Management, 11, 49-6o. https:// doi.org/10.1111/1468-5973.1102001

Procopio, C. H., \& Procopio, S. T. (2007). Do you know what it means to miss New Orleans? Internet communication, geographic community, and social capital in crisis. Journal of Applied Communication Research, 35, 67-87. https://doi. org/10.1080/00909880601065722

Seeger, M., \& Ulmer, R. R. (2002). A post-crisis discourse of renewal: The cases of Malden Mills and Cole Hardwoods. Journal of Applied Communication Research, 30, 126-142. https://doi.org/10.1080/00909880216578

Seeger, M. W., Ulmer, R. R., Novak, J. M., \& Sellnow, T. L. (2005). Post-crisis discourse and organizational change, failure and renewal. Journal of Organizational Change Management, 18(1), 78-95. https://doi.org/10.1108/09534810510579869

Simola, S. (2003). Ethics of justice and care in corporate crisis management. Journal of Business Ethics, 46(4), 351-361. https:// doi.org/10.1023/A:1025607928196

Solomon, Z. (2003). Coping with war-induced stress: The Gulf War and the Israeli response. Plenum Press.

Sturges, D. L. (1994). Communicating through crisis: A strategy for organizational survival. Management Communication Quarterly, 7, 297-316, https://doi.org/10.1177/089331899400 7003004

Ulmer, R. R., \& Sellnow, T. L. (2002). Crisis management and the discourse of renewal: Understanding the potential for positive outcomes of crisis. Public Relations Review, 28, 361-365. https://doi.org/10.1016/So363-8111(02)00165-0

Ulmer, R. R., Sellnow, T. L., \& Seeger, M. W. (2007). Effective crisis communication: Moving from crisis to opportunity. Sage. 
Utz, S., Schultz, F., \& Glocka, S. (2013). Crisis communication online: How medium, crisis type and emotions affected public reactions in the Fukushima Daiichi nuclear disaster. Public Relations Review, 39, 40-46. https://doi.org/10.1016/j. pubrev.2012.09.010

Waymer, D., \& Heath, R. L. (2007) Emergent agents: The forgotten publics in crisis communication and issues management research. Journal of Applied Communication Research, 35(1), 88-108. https://doi.org/10.1080/00909880601065730

Wombacher, K., Herovic, E., Sellnow, T. L., \& Seeger, M. W. (2018). The complexities of place in crisis renewal discourse: A case study of the Sandy Hook Elementary School shooting. Journal of Contingencies and Crisis Management, 26, 164-172. https:// doi.org/10.1111/1468-5973.12186

$\mathrm{Xu}$, S. (2018). Crisis communication within a community: Bonding, coping, and making sense together. Public Relations Review, 44(1), 84-97. https://doi.org/10.1016/j. pubrev.2017.10.004 